\title{
Comparing the historic olive trees (Olea europaea L.) of Santa Cruz Island with contemporaneous trees in the Santa Barbara, CA area: a case study of diversity and structure in an introduced agricultural species conserved in situ
}

\author{
D. Soleri • A. Koehmstedt • M. K. Aradhya $\cdot$ \\ V. Polito $\cdot$ K. Pinney
}

Received: 28 April 2009/Accepted: 25 January 2010/Published online: 24 February 2010

(C) The Author(s) 2010. This article is published with open access at Springerlink.com

\begin{abstract}
Historic populations of crop species outside their centers of origin and diversity, like the domestic olive (Olea europaea L.) in North America, are genetic resources for contemporary agriculture, including genotypes that could be readily evaluated for, and may be adapted to, local conditions. The primary goal of this study was to describe the diversity and structure of several significant, adjacent, contemporaneous historic olive plantings in central coastal California, USA with reference to the USDA ex situ Olea europaea germplasm, and test the hypothesis that physical and chronological proximity are predictive of genetic similarity in those trees. The groups studied using 14 SSR markers were dominated by a limited number of genotypes represented in the USDA collection, but also four unique cultivar genotypes not in that collection. Historical socioeconomic networks appear to have had an important influence on the source and kind of material planted. This is the first study of historic olive trees conserved
\end{abstract}

D. Soleri $(\bowtie)$

Geography Department, University of California,

Santa Barbara, CA, USA

e-mail: soleri@es.ucsb.edu

\section{A. Koehmstedt - M. K. Aradhya}

USDA Germplasm Repository, University of California,

Davis, CA, USA

A. Koehmstedt · V. Polito $\cdot$ K. Pinney

Department of Plant Sciences, University of California,

Davis, CA, USA in situ in North America and provides the basis for a larger regional study integrating genetic, historical and geographic data to describe the structure and diversity of remaining historic olive plantings in California.

Keywords California USA .

Crop genetic resources - Crop introduction Gene flow - Geographic distribution .

In situ conservation - Olive - Olea europaea .

SSRs
Abbreviations
SSR
Simple sequence repeat
GIS Geographic information system
USDA NCGR United States Department of Agriculture National Clonal Germplasm Repository

\section{Introduction}

Understanding the movement of crop species and genes out of their centers of origin can provide valuable historic and agricultural information (Rebourg et al. 2003). Long distance gene flow in agricultural plants is complex and can be biologically and socially significant (Crosby 2003), e.g., the northern movement and convergence of northern flint and southern dent maize, Ukrainian red winter wheat brought to the US (Cox 1991: 26), maize to Africa in 
the 17th century, and today, US transgenes into local maize populations in central and southern Mexico (Piñeyro-Nelson et al. 2009, Serratos-Hernández et al. 2007). Historic populations of crop species are genetic resources for contemporary agriculture, including genotypes that could be readily evaluated and may be adapted to local conditions. This may be particularly useful for long lived species outside of their native regions such as the domestic olive (Olea europaea L.) in North America where historic plantings represent genotypes that have survived conserved in situ for up to 200 years, or selections of new useful genotypes resulting from somatic mutations and/or cross pollination and seed propagation.

In olive, a combination of propagation via seed and vegetative clones has resulted in distinct population structures. Olives have been clonally propagated for millennia (Zohary and Hopf 2000), however, seedlings are also used, were a source of regionally specific genotypes in the evolution of the domesticated olive (Breton et al. 2006), and may have been encouraged by farmers as a source of new diversity, as observed in other clonally propagated crops (e.g., cassava, Elias et al. 2001). Understanding the distribution and diversity of O. europaea in the New World is important for the conservation and use of those populations. For example, farmers and nurseries involved in the burgeoning olive oil business in California USA are interested in trying new cultivars. Acquisition, importation and then state and federal quarantine requirements before new material can be released for commercial planting can all result in substantial investment of time and resources. In contrast, genetic identification of existing historic olive populations and individuals along with observations of their yield potential, fruit and oil quality, pest and disease resistance and other characteristics could lead to rapid propagation and planting of desirable genotypes, as well as their salvage, or their elimination in areas where Olea are considered invasive. However, lack of information about early olive material in that region and in what form(s) and by which processes it was dispersed, means that the actual structure and diversity present in historic plantings today is unknown.

The common perception is that historic olive trees in California are dominated by the 'Mission' cultivar originally introduced by Spanish missionaries to the present day Caribbean and central Mexico in the early 1500s (Taylor 2000: 11-16) and then dispersed to the
Mediterranean climates of the western North American continent and to a lesser extent to South America (e.g., Peru) over the subsequent 200 years. The diversity present within the original mission plantings in NW Mexico and California is unknown; 'Mission' is a cultivar specific to North America and because the details of its early history are unclear this name may have been applied to different genetic entities by different people. For example, in 1905 Porter states "for nearly 100 years the only variety (in California) was the 'Mission olive', and the larger number of the original trees were planted from seed" (Porter 1905: 60) which would have resulted in a heterogeneous population. California State Secretary of Agriculture BM Lelong noted in 1888 that "there are several 'types' of what are known to be the 'Mission' olive. Different 'types' are found in almost every old orchard in the state" (Lelong 1888: 18), suggesting a multiline population of several repeated genotypes. Contemporary extension publications also recognize multiple "strains" of the 'Mission' cultivar in California (Sibbett and Ferguson 2005: 45). New cultivar diversity began to be introduced to the area starting in the mid 1800s, particularly centered in San Francisco and stimulated by the gold rush and accompanying economic boom there (Taylor 2000: 96ff). Still, for lack of research, the situation has remained parallel to that noted in a study of European maize populations: "The main discourse concerning the spread of maize in Europe still refers...to a pattern of dispersion starting from its first introduction in Spain" (Rebourg et al. 2003). Historic California olive genotypes have been presumed to be limited to the 'Mission' cultivar, spread northward through the mission system beginning in the late 1700 s.

Lacking other information, as with olives in California, exploration and sampling of in situ crop genetic resources adheres to a spatial approach informed by population genetics, most recently formalized through the application of geographic information systems (GIS) (e.g., Greene and Hart 1999, Guarino et al. 1999). This interdisciplinary approach reflects the concept of population divergence resulting from natural selection and the idea that "excessive effort at any one site will seriously reduce the efficiency of the (sampling) mission" (Brown 1999: 43). This approach parallels Tobler's First Law of Geography: "everything is related to everything else, but near things are more related than distant things" 
(Tobler 1970: 236); spatial proximity predicts similarity and relatedness, spatial autocorrelation is present. Using such a spatial approach this research is a case study focusing on historic olives in a limited geographic area of coastal central California, USA. Our primary goal was to describe the structure and diversity of historic olive trees on Santa Cruz Island, compare that with other significant, nearby contemporaneous plantings, and test the hypothesis that physical and chronological proximity are predictive of genetic similarity in those trees outside their Mediterranean center of origin and diversity. This is an initial step in a planned regional study with the current research contributing to the (a) development of a sampling strategy for that regional study of historic olive genetic resources, and (b) understanding and documentation of historic gene flow in an agricultural species outside its center of origin and diversity.

\section{History of olives in the Santa Barbara area}

Olives were likely introduced to the central California coast at the end of the 18th century with the movement of Franciscan missionaries north through what they referred to as "Baja" and then "Alta California" (Taylor 2000). The Santa Barbara Mission was established in 1786 and while there is no documentation of the year the olives were planted, a French traveler noted the presence of "fine olive trees" shading Mission paths there in 1827 (Geiger 1965: 5455). The second period of olive planting in the Santa Barbara area began after the secularization of the Catholic church in Mexico in 1835 (California was at that time part of Mexico), leading to the decline of the missions and rise of large agricultural properties and land grants in the mid to late 1800s. Starting then, a number of prominent Anglo American entrepreneurs, some of them lay horticulturalists, experimented with diverse plant species in their search for new business opportunities. Enthusiastic endorsements of olive oil production as a lucrative business can be found in many promotional publications from that time. Ellwood Cooper of Santa Barbara was the leader of this movement, claiming to have planted 12,500 trees on his ranch, propagated from rooted cuttings from mission trees in approximately 1870 (Cooper 1993: 39). From 1869 to 1937 the Santa Cruz Island (SCI) Company ranched and farmed the largest of the California Channel Islands that lies approximately
$40 \mathrm{~km}$ off the Santa Barbara coast. The owner for most of this period was Justinian Caire, a French, San Francisco-based businessman. The company maintained a regular ferry service to San Francisco, obtaining most of its provisions, including agricultural supplies, from there (Gherini 1997). Caire had two groves of olives planted on the island in 1886-1887 (SCIC 1887). We speculate that these were probably intended for oil production, given the popularity at the time, and because Caire was a board member of a statewide association of olive producers chaired by Cooper (California State Board of Agriculture 1892: 354-355). However, no evidence of island oil production or sales has been found. In 1893 Carlo Bottiani from Genoa, Italy-the first "registered" Italian resident of the Goleta Valley of Santa Barbara (Tompkins 1976: 203)—planted a grove of trees for oil production, though the source of this planting material is unknown (C Bottiani, Jr., personal communication October 2004). Bottiani entered California through San Francisco in 1885, living there prior to coming to work in Santa Barbara, and returned to San Francisco to await the arrival of his wife and brother in 1892. In 1919, toward the end of this period of entrepreneurial experimentation with olives in California, the City of Santa Barbara planted the newly developed Olive Street with approximately 350 olive trees obtained from the Los Angeles area. Through a contract with the city, those trees were harvested through the late 1950s by a small oil producer based in the Los Angeles area (Tino Ziliotto, personal communication March 2005). Thus olive trees at the Santa Barbara Mission, in Cooper's grove and along Olive Street are thought to have been procured from the Santa Barbara area or to the south. Historical evidence indicates closer ties to the San Francisco area for those who planted the Bottiani and SCI olive groves. Trees from all five of these plantings (Santa Barbara Mission, Cooper, SCI, Bottiani, Olive Street) were included in the research reported here.

\section{Materials and methods}

\section{GIS}

A GIS was constructed using ArcView 3.3 (ESRI, Inc 2002). Olive plantings, sampled as described below, were documented on site with a Garmin etrex GPS unit 
and downloaded onto the base GIS using Waypoint + (http://www.tapr.org/ kh2z/Waypoint/). Large, intact plantings included in this study (Cooper, Bottiani, SCI groves) were converted to polygons.

\section{Sample selection}

Historical information about olive cultivation in the Santa Barbara area was used to define a small sample of plantings that were historically significant, persistent and verifiable (Fig. 1). The initial SCI cultivar sample $(n=84)$ was stratified between the two groves (north and south), with transects walked and sampled in each for a total of 31 trees in the south grove, 50 in the larger north grove (approximately 26 and $15 \%$ of each grove, respectively) (Fig. 2). Three individuals growing close to nearby island ranch houses completed the sample of intentionally planted trees on the island. In addition, ten presumably feral trees growing adjacent to island groves were sampled. For the other plantings, where a small number of trees survived, a complete sample of all remaining trees was taken (Santa Barbara Mission area), or a small, spatially distributed, opportunistic sample of trees in a larger planting was taken (Cooper, Bottiani, Olive Street) (Table 1). Trees were organized into the following groups based on physical location and historical data: (1) Presumed original plantings at the Santa Barbara Mission; (2) SCI; (3) Other Santa Barbara (Cooper, Bottiani, Olive Street).

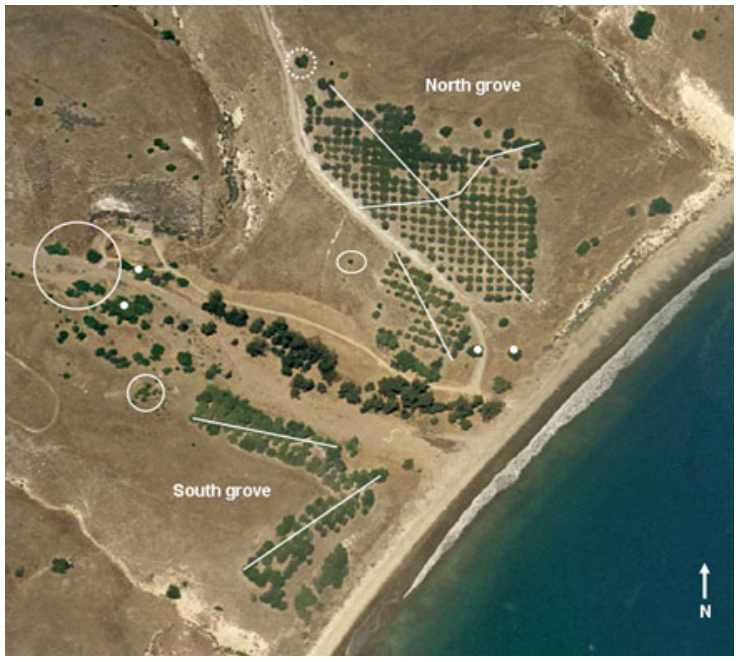

Fig. 2 Santa Cruz Island olive groves and sampling transects

Genetic analysis

For genetic analysis three to six new leaves were taken from each tree in March 2005, or August 2007. DNA extraction was from fresh leaf tissue in all cases except 13 Santa Cruz Island samples where dry leaf tissue was used. Leaf tissue was homogenized by first freezing in liquid nitrogen, then grinding with a mortar and pestle. DNA was extracted from homogenized tissue using either QIAGEN DNeasy Plant Mini-prep Kits (QIAGEN, Valencia, CA), or a CTAB-based protocol modified from Doyle and Doyle (Doyle and Doyle 1987).
Fig. 1 Historic plantings included in this study

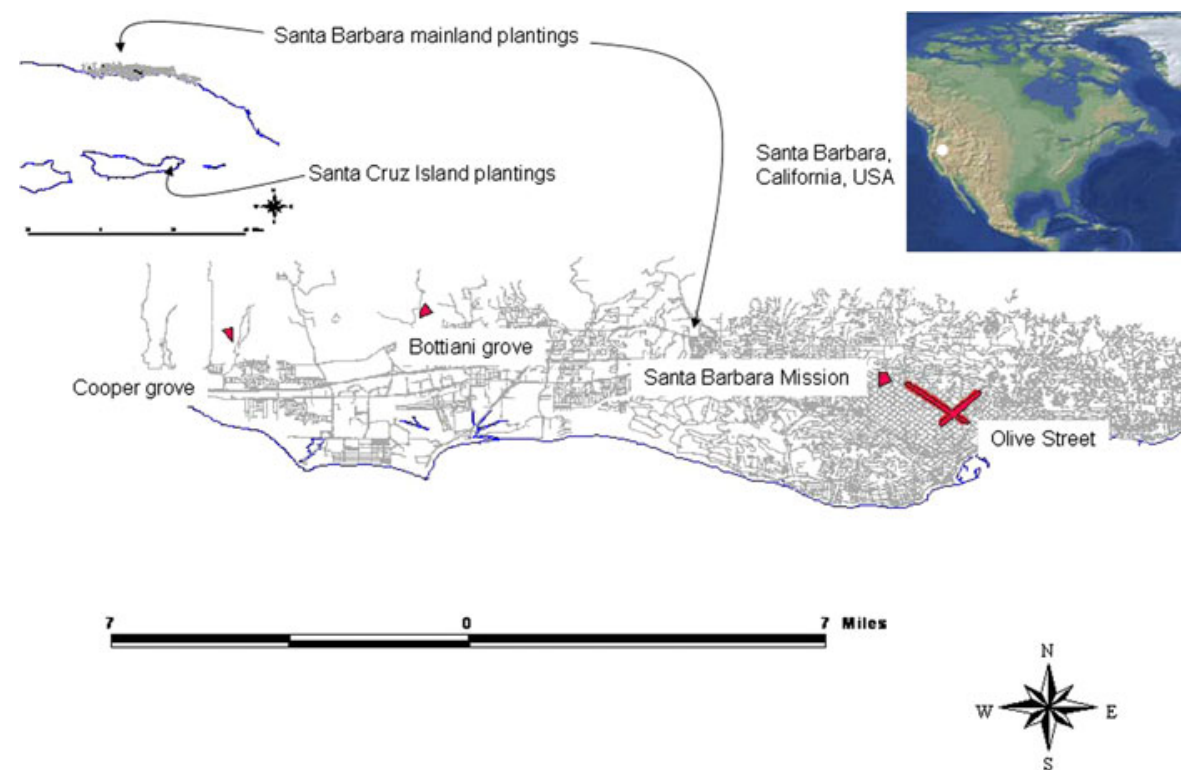


Table 1 Historic olive plantings included in this study

\begin{tabular}{|c|c|c|c|c|c|}
\hline \multirow[t]{2}{*}{ Group } & \multirow[t]{2}{*}{ Planting } & \multirow[t]{2}{*}{ Year planted } & \multicolumn{2}{|c|}{ Approximate number of trees } & \multirow[t]{2}{*}{ Sample size } \\
\hline & & & Originally & Currently & \\
\hline Santa Barbara Mission & Santa Barbara Mission & $\sim 1786-1800^{\mathrm{a}}$ & NA & 20 & 15 \\
\hline \multirow[t]{4}{*}{ Other Santa Barbara } & & & 13,100 & 445 & 29 \\
\hline & Elwood Cooper & $1870^{\mathrm{b}}$ & 12,500 & 70 & 13 \\
\hline & Bottiani family & $1893^{\mathrm{c}}$ & 250 & 80 & 10 \\
\hline & Olive street & $1919^{\mathrm{d}}$ & 350 & 295 & 6 \\
\hline Santa Cruz Island & & $1886-1887^{\mathrm{e}}$ & 600 & 451 & 94 \\
\hline \multirow{4}{*}{$\begin{array}{l}\text { Presumed intentionally } \\
\text { planted cultivars }\end{array}$} & & & & & 84 \\
\hline & North grove & & 400 & 329 & 50 \\
\hline & South grove & & 200 & 119 & 31 \\
\hline & Individuals near ranch house & & Unknown & 3 & 3 \\
\hline Presumed feral & & - & - & - & 10 \\
\hline Total & & & 13,700 & 916 & 138 \\
\hline
\end{tabular}

a Mission founded 1786, trees "mature" in 1827 (Geiger 1965: 54-55)

b Cooper 1993: 39

c Carlo Bottiani, personal communication 2005 Mar 10

d Redmon 2003

e SCIC 1887

Fourteen SSR primers identified in previous research were used in this study (Table 2). These same primers have recently been used to genotype the USDA NCGR Olea germplasm collection (www. ars.usda.gov/Main/docs.htm?docid=12870) in Davis, CA (Koehmstedt 2009). Cultivar identification for trees in the Santa Barbara study was based on SSR genotypes identical to named USDA accessions. One of each primer pair was labeled with one of three fluorescent dyes: 6-FAM, HEX, or NED [Applied Biosystems, Foster City, CA (ABI)]. Each PCR solution consisted of $1 \times$ Standard Taq Buffer [New England BioLabs, Ipswich, MA (NEB)], $2 \mathrm{mM} \mathrm{MgCl}_{2}, 0.375 \mathrm{mM}$ each dNTP (ABI), 0.075 units/ $\mu 1$ Taq DNA Polymerase (NEB), $0.05 \mathrm{pmol} / \mu \mathrm{l}$ each primer, and approximately $5 \mathrm{ng} / \mu \mathrm{l}$ DNA. PCR reactions were triplexed (made with three primer pairs combined in one reaction), each pair labeled with a different fluorescent dye. PCR was completed under the following conditions: one cycle of $94^{\circ} \mathrm{C}$ for $5 \mathrm{~min}, 30$ cycles of $94^{\circ} \mathrm{C}$ for $30 \mathrm{~s}, 55^{\circ} \mathrm{C}$ for $30 \mathrm{~s}$, and $72^{\circ} \mathrm{C}$ for $40 \mathrm{~s}$, and then a final elongation of $72^{\circ} \mathrm{C}$ for $7 \mathrm{~min}$. Fragment separation by capillary electrophoresis was conducted on a 3100 Genetic Analyzer (ABI).
Data analysis

SSR fragments were sized in base pairs and binned into allele categories using GeneScan Analysis Software v. 3.1 and Genotyper v. 2.5 (ABI). Allelic data for all loci were combined into a rectangular data matrix for analysis. Using BIOSYS-1, v. 1.7 (Swofford et al. 1989), a distance matrix was computed using the Prevosti measure, that was then used to produce a distance-Wagner tree, midpoint rooted and optimized for shortest branch length (Swofford 1981, Wright 1978). Unbiased, mean observed heterozygosity and Wright's F-statistics were also calculated using BIOSYS-1 (Nei 1978, Wright 1978). Shannon, evenness and complementary Simpson indices of diversity (Magurran 1988: 34, 39) were calculated for SSR genotypes by planting group.

\section{Results}

Cultivar identification

The individuals sampled for this study include SSR genotypes matching those of four cultivars in the 
Table 2 SSR primers used in this study

\begin{tabular}{lll}
\hline Primer & Fluorescent dye label & Citation \\
\hline EM03 & Fam & De La Rosa et al. 2002 \\
EM030 & Fam & De La Rosa et al. 2002 \\
EM088 & Fam & De La Rosa et al. 2002 \\
EM090 & Fam & De La Rosa et al. 2002 \\
GAPU89 & Hex & Carriero et al. 2002 \\
IAS-oli12 & Fam & Rallo et al. 2000 \\
IAS-oli16 & Ned & GenBank \# AJ748722; Rallo et al. 2000 \\
ssrOeUA-DCA3 & Ned & Sefc et al. 2000 \\
ssrOeUA-DCA8 & Ned & Sefc et al. 2000 \\
ssrOeUA-DCA11 & Ned & Sefc et al. 2000 \\
UDO99-011 & Hex & Cipriani et al. 2002 \\
UDO99-019 & Hex & Cipriani et al. 2002 \\
UDO99-028 & Hex & Cipriani et al. 2002 \\
UDO99-042 & Hex & Cipriani et al. 2002 \\
\hline
\end{tabular}

USDA collection ('Mission', 'Nevadillo', 'Manzanillo', and 'Redding Picholine'), as well as a total of thirteen unique genotypes) - nine on SCI and four in the Bottiani family grove (Table 3 ). Unique genotypes had no duplicates in this study or in the USDA collection and were identified as either feral or as a cultivar not present in the USDA reference population. Trees occurring in the evident planting pattern of a grove and displaying unique genotypes including alleles other than those present in other grove trees sampled were interpreted as unidentified cultivars. Trees occurring outside the obvious grove planting pattern, with genotypes composed of combinations of alleles occurring in other sampled grove trees were considered feral. The nine unique island genotypes (eight originally presumed feral, one originally presumed to have been intentionally planted) share all but one allele with the two high frequency genotypes in that sample ('Mission' [27\%], 'Redding Picholine' [64\%]), suggesting they are feral progeny of the grove trees. Feral olive trees are considered an invasive species on SCI where over 14,000 seedlings have been removed by the Park Service over the last several years (P Power, Channel Island National Park ecologist, personal communication January 2010), consistent with early observations of a high germination rate for 'Redding Picholine' (Bioletti and Flossfeder 1916).

Three of the nine unique SCI individuals have a rare allele (ssrOeUA-DCA8, $132 \mathrm{bp}$ ) only present in one other genotype within the NCGR collection
(Tunisian cultivar 'Chitoni') to which these trees are not otherwise similar. This allele is within two to six bp of the only other three alleles at this locus (134, 136, 138) among SCI genotypes, and may be the result of a somatic mutation in a grove tree that was a parent of these putative feral seedlings, a phenomenon encountered in other studies of olive diversity (e.g., Cipriani et al. 2002: 226). Alternatively, this allele may be representative of other cultivar genotypes not included in our sample, a hypothesis that can be tested in the future through more extensive sampling. Two other island trees on the far NW end of the northern grove presumed to be feral are cultivar genotypes and so were likely intentionally planted.

Most Santa Barbara Mission trees were 'Mission' genotypes, with two corresponding to the USDA accession for 'Manzanillo' supporting one version of those two trees' history suggesting they were not part of the original planting but brought in more recently. These two trees are located next to one another and well within the original Mission planting area, closer to the Mission itself than the majority of other trees in this group. Other Santa Barbara plantings were also dominated by 'Mission' genotypes $(100 \%$ of the Cooper sample) with a small number of 'Nevadillo' and 'Manzanillo' individuals, and four unique genotypes from the Bottiani grove. Cooper stated that he took cuttings from different mission plantings (Santa Barbara, San Fernando, San Diego) and the Tajiguas ranch NW of Santa Barbara established in the late 
Table 3 Cultivar identification based on SSR genotypes of USDA olive collection

\begin{tabular}{|c|c|c|c|c|c|c|c|c|c|c|c|c|}
\hline \multirow[t]{3}{*}{ Group/planting } & \multicolumn{10}{|c|}{ Percent (number) of individuals with SSR genotype in each group } & \multirow{2}{*}{\multicolumn{2}{|c|}{ Total }} \\
\hline & \multicolumn{2}{|c|}{ Mission $^{\mathrm{a}}$} & \multicolumn{2}{|c|}{ Redding Picholine ${ }^{\mathrm{b}}$} & \multicolumn{2}{|c|}{ Nevadillo $^{\mathrm{c}}$} & \multicolumn{2}{|c|}{ Manzanillo $^{\mathrm{d}}$} & \multicolumn{2}{|c|}{ Unique $^{\mathrm{e}}$} & & \\
\hline & $\%$ & No. & $\%$ & No. & $\%$ & No. & $\%$ & No. & $\%$ & No. & $\%$ & No. \\
\hline Santa Barbara Mission & 86.67 & 13 & 0.00 & 0 & 0.00 & 0 & 13.33 & 2 & 0.00 & 0 & 100.00 & 15 \\
\hline Other Santa Barbara & 75.86 & 22 & 0.00 & 0 & 6.90 & 2 & 3.45 & 1 & 13.79 & 4 & 100.00 & 29 \\
\hline Elwood Cooper & 100.00 & 13 & 0.00 & 0 & 0.00 & 0 & 0.00 & 0 & 0.00 & 0 & 100.00 & 13 \\
\hline Bottiani family & 54.55 & 6 & 0.00 & 0 & 9.09 & 1 & 0.00 & 0 & 36.36 & 4 & 100.00 & 11 \\
\hline Olive Street & 60.00 & 3 & 0.00 & 0 & 20.00 & 1 & 20.00 & 1 & 0.00 & 0 & 100.00 & 5 \\
\hline Santa Cruz Island & 26.60 & 25 & 63.83 & 60 & 0.00 & 0 & 0.00 & 0 & 9.57 & 9 & 100.00 & 94 \\
\hline North grove & 18.00 & 9 & 80.00 & 40 & 0.00 & 0 & 0.00 & 0 & 2.00 & 1 & 100.00 & 50 \\
\hline South grove & 41.94 & 13 & 58.06 & 18 & 0.00 & 0 & 0.00 & 0 & 0.00 & 0 & 100.00 & 31 \\
\hline Ranch houses & 66.67 & 2 & 33.33 & 1 & 0.00 & 0 & 0.00 & 0 & 0.00 & 0 & 100.00 & 3 \\
\hline Presumed ferals & 10.00 & 1 & 10.00 & 1 & 0.00 & 0 & 0.00 & 0 & 80.00 & 8 & 100.00 & 10 \\
\hline Grand total & 43.48 & 60 & 43.48 & 60 & 1.45 & 2 & 2.17 & 3 & 9.42 & 13 & 100.00 & 138 \\
\hline \multicolumn{13}{|c|}{${ }^{\mathrm{a}}$ USDA accession DOLE0057 } \\
\hline \multicolumn{13}{|c|}{ b USDA accession DOLE0071 } \\
\hline \multicolumn{13}{|c|}{ 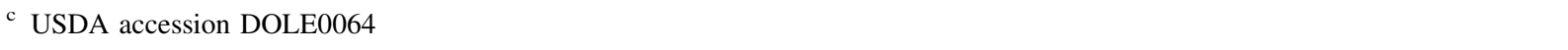 } \\
\hline \multicolumn{13}{|c|}{${ }^{\mathrm{d}}$ USDA accession DOLE0141 } \\
\hline
\end{tabular}

1790s (Taylor 2000: 42). If that is correct then our finding of a single genotype in his grove supports the hypothesis of extensive clonal propagation of a very limited number of genotypes as the missions moved northward, evidence of a founder effect in the form of a tight genetic bottleneck in the first century of the introduction of this Mediterranean crop to the area of contemporary California.

Genetic diversity

Allelic diversity among the fourteen SSR markers ranged from two to a maximum of seven per locus, with a total of 62 alleles identified in this study. The number of unique genotypes per marker ranged from two to ten (Table 4). The small number of alleles detected in this sample relative to others for some of the same SSR markers is an indication of the lack of diversity in this small sample from outside the center of O. europaea origin and diversity (Table 5). While this indicates the relative lack of diversity in the Santa Barbara area, it is not indicative of overall diversity of historic cultivated olive in North America as that may only be assessed by including material representing the geographic distribution and history of multiple cultivar introductions to that region, and is likely to be greater. A study including invasive progeny of cultivated olive in Australia (Besnard et al. 2007) found no significant reduction in allelic richness or gene diversity in those progeny compared to a reference cultivated population in Algeria, hypothesizing this to be the result of multiple introductions of diverse cultivated genotypes over time into Australia. Should there be similar results found when a larger sample of North American historical olives are sampled, our data would support the presence of history-based population structure in some areas of that region.

At the level of alleles, the high direct-count average heterozygosity value vs. the expected Hardy-Weinberg value in the Other Santa Barbara and Mission groups (Table 6) indicates excess heterozygosity, likely the result of selection in cultivar development for production traits such as large fruit size or oil content associated with heterozygosity. The SCI group appears to be in Hardy-Weinberg equilibrium, likely an artifact of the chance allelic diversity present between the 'Mission' and 'Redding Picholine' genotypes which share only $17 \%$ (7/42) of the 42 alleles found in those two genotypes for 
Table 4 SSR marker alleles and genotypes present in this study

\begin{tabular}{lllc}
\hline SSR marker & Alleles (bp) & $\begin{array}{l}\text { Total number of } \\
\text { alleles for marker }\end{array}$ & $\begin{array}{l}\text { Number of unique } \\
\text { genotypes for marker }\end{array}$ \\
\hline EM03 & 209, 211, 213, 217 & 4 & 6 \\
EM030 & $185,187,189$ & 3 & 4 \\
EM088 & $184,186,198$ & 3 & 4 \\
EM090 & $184,186,190$ & 3 & 4 \\
GAPU89 & $156,158,194,205$ & 4 & 7 \\
IAS-oli12 & $112,114,120,121,123$ & 5 & 7 \\
IAS-oli16 & $146,150,151,154,156,160,164$ & 7 & 8 \\
ssrOeUA-DCA3 & $236,238,242,244,248,252$ & 6 & 8 \\
ssrOeUA-DCA8 & $132,134,136,138,140$ & 5 & 9 \\
ssrOeUA-DCA11 & $131,141,147,161$ & 4 & 5 \\
UDO99-011 & $89,109,111,113,121,125,127$ & 7 & 10 \\
UDO99-019 & 129,143 & 2 & 2 \\
UDO99-028 & $121,123,131,147,149$ & 5 & 7 \\
UDO99-042 & $140,144,146,148$ & 4 & 5 \\
Totals & & 62 & 84 \\
\hline
\end{tabular}

Table 5 Number of alleles detected for SSR markers common to this and other recent studies

\begin{tabular}{|c|c|c|c|c|c|}
\hline \multirow[t]{3}{*}{ SSR marker } & \multicolumn{5}{|c|}{ Total number of alleles for marker } \\
\hline & \multirow[t]{2}{*}{ Lopes et al. 2004} & \multirow[t]{2}{*}{ Sarri et al. 2006} & \multirow[t]{2}{*}{ Besnard et al. 2007} & \multicolumn{2}{|l|}{ This study } \\
\hline & & & & & $\begin{array}{l}\text { Number of alleles as } \\
\text { proportion of maximum } \\
\text { number in other studies }\end{array}$ \\
\hline Number named cvs sampled & 67 & 118 & Unknown & Unknown & \\
\hline Number trees sampled & 130 & 127 & 34 & 138 & \\
\hline GAPU89 & na & 10 & na & 4 & 0.400 \\
\hline EM03 & na & na & 11 & 4 & 0.364 \\
\hline ssrOeUA-DCA3 & 11 & 9 & 6 & 6 & 0.545 \\
\hline ssrOeUA-DCA8 & 8 & 16 & 14 & 5 & 0.313 \\
\hline ssrOeUA-DCA11 & 11 & 17 & na & 4 & 0.235 \\
\hline
\end{tabular}

markers used in this study. The distribution of those two genotypes is significantly different in the north and south groves $\left(\chi^{2}=5.2899, P=0.0214\right)$, possibly because they were planted a year apart drawing on a different mix of planting stock. Overall, low diversity in these planting groups indicates collections of a limited number of clonally propagated genotypes rather than multiline cultivars or interbreeding populations.

Among groups, the distribution of genotypic diversity (Table 7) is characterized by the dominance of the Santa Barbara Mission group by the 'Mission' cultivar (complementary Simpson index $=0.248$ ), the relatively balanced representation of two cultivars in SCI genotypes (evenness $=0.874$ ), and the relatively higher diversity in the Other Santa Barbara group (Shannon index $=0.978$ ).

The mean $\mathrm{F}_{\mathrm{ST}}$ of 0.173 for all groups of trees included in this study indicates that those groups differ significantly, but only very moderately. In cluster analysis the Mission and Other Santa Barbara samples are more similar to each other genetically than the SCI group (Fig. 3). Some of this separation is likely because the most frequent SCI genotype, 
Table 6 Genetic variability at 14 loci in all groups (standard errors in parentheses)

\begin{tabular}{|c|c|c|c|c|c|}
\hline \multirow[t]{2}{*}{ Group } & \multirow{2}{*}{$\begin{array}{l}\text { Mean sample } \\
\text { size per locus }\end{array}$} & \multirow{2}{*}{$\begin{array}{l}\text { Mean no of } \\
\text { alleles per locus }\end{array}$} & \multirow{2}{*}{$\begin{array}{l}\text { Percentage of } \\
\text { loci polymorphic }\end{array}$} & \multicolumn{2}{|c|}{ Mean heterozygosity } \\
\hline & & & & Direct count & HW expected ${ }^{b}$ \\
\hline Santa Barbara Mission & $14.9(0.1)$ & $2.1(0.2)$ & 86.7 & $0.622(0.124)$ & 0.379 \\
\hline Other Santa Barbara & $28.7(0.2)$ & $3.3(0.3)$ & 86.7 & $0.605(0.113)$ & 0.402 \\
\hline Santa Cruz Island & $91.9(1.0)$ & $2.9(0.3)$ & 93.3 & $0.639(0.102)$ & 0.535 \\
\hline
\end{tabular}

${ }^{a}$ A locus is considered polymorphic if the frequency of the most common allele does not exceed 0.95

b Unbiased estimate (Nei 1978)

Table 7 Diversity indices ${ }^{a}$ for genotype distributions in greater Santa Barbara olive planting groups in this study

\begin{tabular}{llllll}
\hline Group & $\begin{array}{l}\text { No } \\
\text { individuals }\end{array}$ & $\begin{array}{l}\text { Genotypic } \\
\text { richness }\end{array}$ & $\begin{array}{l}\text { Complementary } \\
\text { Simpson index }\end{array}$ & $\begin{array}{l}\text { Evenness } \\
\text { index }\end{array}$ & $\begin{array}{l}\text { Shannon } \\
\text { index }\end{array}$ \\
\hline Santa Barbara Mission & 15 & 2 & 0.248 & 0.567 & 0.393 \\
Other Santa Barbara & 29 & 7 & 0.429 & 0.501 & 0.978 \\
Santa Cruz Island & $85^{\mathrm{c}}$ & 2 & 0.420 & 0.874 & 0.606 \\
\hline
\end{tabular}

'Feral' genotypes not included

a Magurran 1988: 34-40

b $\left(1-\mathrm{D}_{\mathrm{S}}\right) ; \mathrm{D}_{\mathrm{S}}=$ Simpson diversity index

c $85=84$ intentionally planted within the grove layout +1 previously presumed feral but with cultivar SSR genotype

'Redding Picholine', is not present in either Other Santa Barbara or Mission groups, and because that genotype has one allele not found in the rest of the trees sampled for this study: SSR UDO99-011, 89 bp. In addition, this allele does not appear in any other accessions in the USDA NCGR collection. 'Redding Picholine' is thought to be a rootstock imported into California in 1872 by BB Redding, a state official and railroad executive based in Sacramento, as the French table cultivar 'Picholine' (Sibbett and Ferguson 2005: 45). Speculation is that this 'Picholine' was a grafted cultivar, the scions did not survive shipment from Europe and the rootstock was mistaken for the scion material (Taylor 2000: 82). By 1888 'Redding Picholine' was recognized as different from the true French 'Picholine', and best used as rootstock (Lelong 1888: 21); it was the seed cultivar featured in an extension booklet on olive seed stock for California in 1916 (Bioletti and Flossfeder 1916), and is still recognized today for this use (Sibbett and Ferguson 2005: 46). At the time of planting (18861887), the trees on Santa Cruz Island were probably thought to be French 'Picholine', but their later identification as rootstock material may explain why there is no evidence of processing, shipping or sales of SCI olives.

\section{Discussion}

To our knowledge this is the first published report including any cultivar genotypes of historic olive trees conserved in situ in North America. We believe this modest case study is significant because it marks the initial stage of genetic characterization of such trees, and investigation into the processes that resulted in the structure of diversity present today. Additionally, it contributes to understanding the extent that in situ genotypes are represented within the formal, ex situ germplasm collection in the region. The scale of the study reflects the time and resources available for this first step which will stimulate future research that must expand coverage of plantings within North America and involve collaboration with colleagues internationally to harmonize methods so that the genetic identities of trees conserved both in and ex situ in the New World may be compared and effectively integrated with global documentation, conservation and use of $O$. europaea genetic resources.

Specifically, for the case of Santa Cruz Island and Santa Barbara, our findings suggest that propagation practices along with historical and geographical circumstances enforced low levels of diversity within and between the historic California olive plantings 
Fig. 3 Distance-Wagner tree showing genetic relatedness among the three groupings of historic olives included in this study
Distance from root

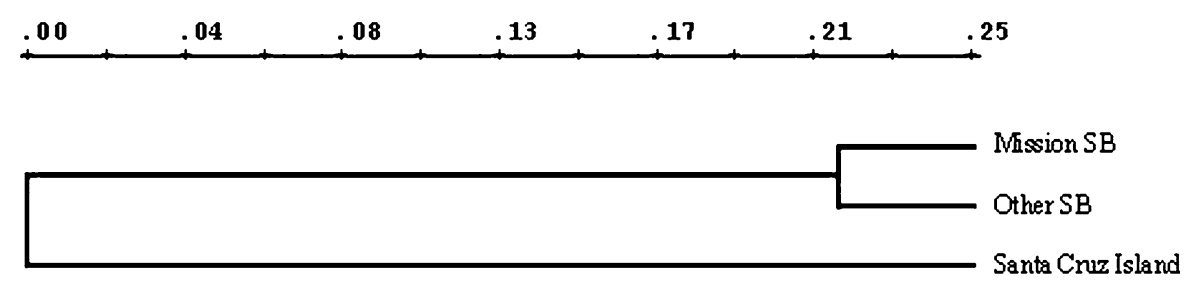

included in this study. The first O. europaea introductions into North America may have had limited diversity or have had diversity reduced via selection in new environments. The null hypothesis that 'Mission' genotype(s) spread northward, forming the foundation of olive plantings until new material was brought in at the end of the 19th century is supported for the Santa Barbara area by our case study. The strong influence of the 'Mission' cultivar as both a proven and accessible genotype can be seen in its persistence in plantings spanning 100 years. At the same time, increased interest in, and availability of, other olive genotypes in California toward the end of the 19th century is reflected even in our limited sample, especially in the plantings presumed to be sourced through San Francisco networks. Though further research is required, plantings established with material that appears to have been obtained from different sources, regions and perhaps socioeconomic networks differ. That is, plantings such as the SCI and perhaps the Bottiani groves with trees likely obtained from northern California instead of the more common practice of sourcing olive material from the south, include different olive cultivars relative to other contemporaneous plantings in the Santa Barbara region that we investigated. The relatively more recent Olive Street planting with 'Mission', 'Nevadillo' and 'Manzanillo' trees present in even our small sample suggests that by the first decade of the 20th century cultivar diversity was increasing in southern California nurseries.

Some of our results have very locally specific relevance. The identification of a large proportion (64\%) of the SCI sample as 'Redding Picholine' is useful in understanding the apparent abandonment of the groves there for fruit or oil processing. That cultivar's historic and contemporary reputation for excellent seedling establishment also helps explain the success of feral trees, like the nine included in this study, as ecological invaders on that island, facilitated by a diversity of vectors: until recently a large population of feral Old World pigs, as well as native bird and small mammal species. A similar diversity of vectors from both original and new environments was observed in the spread of invasive feral olives in Australia (Breton et al. 2008).

The four intentionally planted genotypes in the Bottiani grove that are unique in this study and not represented in the USDA NCGR collection indicate the value of exploring the diversity of historic California olive plantings further: even in a case study of a limited geographical area $3 \%$ of individuals sampled are not in the regional ex situ collection. However, our findings also reject the hypothesis that spatial or even chronological proximity will be entirely informative for determining sampling strategies for crop diversity in historic plantings, especially for long-lived species such as the olive. Historical information beyond basic chronologies and regarding socioeconomic networks that may also influence provenance of propagules can be valuable for increasing sampling coverage and efficiency. This was true for the historic olive planting at Menares, Morocco. This grove has been found to contain unexpectedly high olive diversity, not only because it lies within the Mediterranean center of O. europaea diversity, but also because it is purported to have been planted over 700 years ago as "an important" grove including "young trees probably originating from different areas" (Charafi et al. 2008). There a $6.4 \%$ sample of the grove identified 16 distinct genotypes, whereas our $14 \%$ sample of the SCI grove identified only three cultivar genotypes.

In the case of historic central California olives trees, Tobler's First Law positing a positive correlation between proximity and similarity is violated by historic socioeconomic processes that overlay both spatial and temporal geography in patterns of their own. As a consequence, genetic divergence at the level of cultivar diversity may be present at very fine spatial scales, not primarily due to ongoing local selection of generations of new genotypic recombination's, but rather resulting from those social 
processes that are an apparently significant aspect of gene flow in domesticated species. Similarly Greene et al. (2004) in a study of wild red clover genetic resources found correlations between morphological, genetic and ecogeographic data indicated structure resulting not simply from geographic distance, but even proximal environments that are "geographically distinct" or that create barriers to gene flow-both characteristics which could result from socioeconomic factors just as easily as environmental ones. For this reason, review of the historic record with consideration of the consequences of social networks for spatial distribution may become useful for improving the coverage and efficiency of such conservation work. In this small study, different major plantings established in the mid-late 19th century in the greater Santa Barbara area were the results of different processes, some very localized. As this research is expanded to cover plantings statewide, historical information (planting year, socioeconomic context) will be an informative layer for building the California historic olive tree GIS, helping ensure inclusion of both more and rarer genetic diversity. Such an approach will also help us reconstruct and understand an historic example of gene flow in an agricultural species far beyond its center of origin and diversity.

Acknowledgments We thank the following people for their valuable assistance and insights: Carlo and Nancy Bottiani Jr; Marla Daly, Santa Cruz Island Foundation; Jeff Hemphill, formerly with UCSB; Jeff Howarth, formerly with UCSB; Fermina Murray; Paula Power Channel Island National Park; Tino Ziliotto, The Italian Grocery of Santa Barbara and two anonymous reviewers. Special thanks to Ann Huston Channel Island National Park, for support in many forms including logistical assistance and access to historical reference materials. This research was supported in part by grants from the Pearl Chase Foundation of UC Santa Barbara; USDA-GRCP; and in kind contributions from Channel Island National Park.

Open Access This article is distributed under the terms of the Creative Commons Attribution Noncommercial License which permits any noncommercial use, distribution, and reproduction in any medium, provided the original author(s) and source are credited.

\section{References}

Besnard G, Henry P, Wille L, Cooke D, Chapuis E (2007) On the origin of the invasive olives (Olea europaea L., Oleaceae). Heredity 99:608-619
Bioletti FT, Flossfeder FCH (1916) Growing and grafting olive seedlings. In: College of Agriculture, AES (ed) Berkeley, CA: University of California Press, pp 305-326

Breton C, Besnard G, Berville AA (2006) Using multiple types of molecular markers to understand olive phylogeography. In: Zeder MA, Bradley DG, Emshwiller E, Smith BD (eds) Documenting domestication: new genetic and archeological paradigms. University of California Press, California, pp 143-152

Breton C, Guerin J, Ducatillion C, Médail F, Kull CA, Bervillé A (2008) Taming the wild and 'wilding' the tame: tree breeding and dispersal in Australia and the Mediterranean. Plant Sci 175:197-205

Brown AHD (1999) The genetic structure of crop landraces and the challenge to conserve them in situ on farms. In: Brush SB (ed) Genes in the field: on-farm conservation of crop diversity. Ottawa: Lewis Publishers; IPGRI; IDRC, Boca Raton, pp 29-48

California State Board of Agriculture (1892) California state board of agriculture annual report. California State Board of Agriculture, Sacramento, CA

Carriero F, Fontanazza G, Cellini FF, Giorio G (2002) Identification of simple sequence repeats (SSRs) in olive (Olea europaea L.). Theor Appl Genet 104:301-307

Charafi J, El Meziane A, Moukhli A, Boulouha B, El Modafar C, Khadari B (2008) Menara gardens: a Moroccan olive germplasm collection identified by a SSR locus-based genetic study. Genet Resour Crop Evol 55:893-900

Cipriani G, Marrazzo M, Marconi R, Cimato A, Testolin R (2002) Microsatellite markers isolated in olive (Olea europaea L.) are suitable for individual fingerprinting and reveal polymorphism within ancient cultivars. Theor Appl Genet 104:223-228

Cooper E (1993) Some incidents in the life of Ellwood Cooper. Noticias, Santa Barbara Hist Mus 39:25-44

Cox TS (1991) The contribution of introduced germplasm to the development of US wheat cultivars. In: Shands HL, Wiesner LE (eds) Use of plant introductions in cultivar development. Part 1. Crop Science Society of America, Madison, WI, pp 25-47

Crosby AW (2003) The Columbian exchange: biological and cultural consequences of 1492. Praeger, Westport, CN

De La Rosa R, James CM, Tobutt KR (2002) Isolation and characterization of polymorphic microsatellites in olive (Olea europaea L.) and their transferability to other genera in the Oleaceae. Mol Ecol Notes 2:265-267

Doyle J, Doyle J (1987) A rapid DNA isolation procedure for small quantities of fresh leaf tissue. Phytochem Bull 19:11-15

Elias M, Penet L, Vindry P, McKey D, Panaud O, Robert T (2001) Unmanaged sexual reproduction and the dynamics of genetic diversity of a vegetatively propagated crop plant, cassava (Manihot esculenta Crantz), in a traditional farming system. Mol Ecol 10:1895-1907

Geiger M (1965) Mission Santa Barbara, 1782-1965. Franciscan fathers of California, Santa Barbara, CA

Gherini J (1997) Santa Cruz Island, a history of conflict and diversity. The Arthur Clark Company, Spokane, WA

Greene S, Hart TC (1999) Implementing geographic analysis in germplasm conservation. In: Greene SL, Guarino L (eds) Linking genetic resources and geography: emerging 
strategies for conserving and using crop biodiversity. American Society of Agronomy, Inc, Crop Science Society of America, Inc, Madison, pp 25-36

Greene SL, Gritsenko M, Vandemark G (2004) Relating Morphologic and RAPD marker varlation to collection site environment in wild populations of Red Clover (Trifolium pratense L.). Genet Resour Crop Evol 51:643653

Guarino L, Maxted N, Sawkins MC (1999) Analysis of Georeferenced data and the conservation and use of plant genetic resources. In: Greene SL, Guarino L (eds) Linking genetic resources and geography: emerging strategies for conserving and using crop biodiversity. American Society of Agronomy, Inc, Crop Science Society of America, Inc, Madison, pp 1-24

Koehmstedt A (2009) Analysis of genetic structure and differentiation in olive (Olea europaea L.) using microsatellite markers. M.Sc thesis. University of California, Davis, Davis, CA

Lelong BM (1888) The olive in California. Varieties, budding, grafting, new methods and general observations. California State Board of Agriculture, Sacramento, CA

Lopes MS, Mendoça D, Sefc KM, Sabino Gil F, da Câmara Machado A (2004) Genetic evidence of intra-cultivar variability within Iberian olive cultivars. Hort Sci 39:1562-1565

Magurran AE (1988) Ecological diversity and its measurement. Princeton University Press, Princeton, NJ

Nei M (1978) Estimation of average heterozygosity and genetic distance from a small number of individuals. Genetics 89:583-590

Piñeyro-Nelson A, Van Heerwaarden J, Perales HR, SerratosHernandez JA, Rangel A, Hufford MB, Gepts P, GarayArroyo A, Rivera-Bustamante R, Alvarez-Buylla ER (2009) Transgenes in Mexican maize: molecular evidence and methodological considerations for GMO detection in landrace populations. Mol Ecol 18:750-761

Porter HD (1905) Olive and "Wild Olive" in America with reference to Paul's figure of speech in Rom 11: 13-24. Biblic World 26:59-63

Rallo P, Dorado G, Martín A (2000) Development of simple sequence repeats (SSRs) in olive tree (Olea europaea L.). Theor Appl Genet 104:984-989

Rebourg C, Chastanet M, Gouesnard B, Welcker C, Dubreuil P, Charcosset A (2003) Maize introduction into Europe: the history reviewed in the light of molecular data. Theor Appl Genet 106:895-903
Redmon M (2003) History 101: What is the history of olive cultivation in this area? Santa Barbara Independent, 10: 35, July 2003

Sarri V, Baldoni L, Porceddu A, Cultrera NGM, Contento A, Frediani M, Belaj A, Trujillo I, Cionini PG (2006) Microsatellite markers are powerful tools for discriminating among olive cultivars and assigning them to defined populations. Genome 49:1606-1615

SCIC (1887) Santa Cruz Island Company work diary, 1887. Channel Islands National Park, Cultural Resources Department

Sefc KM, Lopes MS, Mendonça D, Rodrigues Dos Santos M, Laimer Da Câmara Machado M, Da Câmara Machado A (2000) Identification of microsatellite loci in olive (Olea europaea) and their characterization in Italian and Iberian olive trees. Mol Ecol 9:1171-1173

Serratos-Hernández J-A, Gómez-Olivares J-L, Salinas-Arreortua N, Buendía-Rodríguez E, Islas-Gutiérrez F, de-Ita A (2007) Transgenic proteins in maize in the soil conservation area of Federal district, Mexico. Front Ecol Environ 5:247-252

Sibbett GS, Ferguson L (eds) (2005) Olive production manual, 2nd edn. University of California, Sacramento, CA

Swofford D (1981) On the utility of the distance Wagner procedure. In: Funk VA, Brook DR (eds). Advances in cladistics: Proceedings of the first meeting of the Willie Hennig Society. Bronx, New York: New York Botanical Garden, pp 25-43

Swofford D, Selander R, Illinois Natural History Survey (1989) BIOSYS-1 A Computer program for the analysis of allele variation in population genetics and biochemical systematics. Release 1.7. Illinois Natural History Survey, Urbana, IL

Taylor JM (2000) The olive in California: history of an immigrant tree. Ten Speed Press, Berkeley, CA

Tobler WR (1970) A computer movie simulating urban growth in the Detroit region. Econ Geogr 46 (supplement):234240

Tompkins W (1976) Goleta: the good land. Pioneer Publishing, Fresno, CA

Wright S (1978) Evolution and the genetics of populations, Variability within and among natural populations, vol 4. University of Chicago Press, Chicago, IL

Zohary D, Hopf M (2000) Domestication of plants in the old world: the origin and spread of cultivated plants in West Asia, Europe, and the Nile Valley, 3rd edn. Oxford University Press, Oxford 